\title{
Public spaces and social diversity. Editorial to the special issue
}

\author{
Elisabeth Bühler, Zurich
}

There is little agreement as to the precise meaning of public space in the scientific debate (see Staeheli \& Mitchell 2007). The Babylonian confusion surrounding this concept (SELLE 2008) stems from at least three causes: First, there is no clear distinction between the terms public space and public sphere. Second, public space is a normatively loaded term (BELINA 2005), which in research not seldom clouds analytical vision of the construction processes of public spaces. And third, there is currently no consensus on the direction of the changing function of public spaces. In the following, a closer look is taken at these three aspects. The contributions in this special issue are then introduced and positioned within the context of the discussion.

\section{On the relation between the terms public space and public sphere: an attempt at clarification}

For an understanding of the construction processes of (public) spaces and also for distinguishing between the terms public space and public sphere, sociologist MARTINA Löw presented a useful theoretical concept in her book, Raumsoziologie [Sociology of Space] (2001). Löw views spaces as social structures and integrates them in the proceedings of action. The specific quality of spatial structures as compared to other social structures is their physical/material component. Löw defines spatial structures as relational configurations of physical/material objects and persons, which are reproduced recursively through the actions of actors.

Drawing a distinction between a public sphere and a private sphere has been a constitutive principle of civil/democratic societies since the Enlightenment (SCHÄFERs 2003:15). According to Löw (2001:168-172), this fundamental societal structure, which is secured through rules and resources, is formed through a meshwork of various isolatable and recursively reproduced social structures. These are, for example, legal structures that differentiate between private (or civil) law and public law, economic structures with their distinction between (capitalist) private sector and public sector of the economy, and property structures with the distinction between private property and public property. If we join Löw in seeing spaces as recursively reproduced societal structures, then public and private spaces are in principle nothing more than a further isolatable component in the structural interweaving of public sphere/private sphere. From this perspective, public spaces are to be understood as relational con- figurations of physical/material objects and persons. Concretely, public space refers to publicly accessible squares, streets, sidewalks, green spaces or buildings. In these spaces, other partial structures of the public sphere may also be manifested, among them property structures, economic structures and legal structures.

\section{Public spaces as places of democratic participation}

In Western civil societies there is a widespread consensus that a space is «public» if it is accessible to all: that is, if no one is fundamentally excluded a priori from being in that space. From this it is obvious that the rules and resources involved in the constitution of public spaces must comply with democratic principles. Conflicts of interest between different groups - a typical characteristic of socially diverse societies - are to be negotiated democratically; if there are use conflicts in public space, ideally consensus is to be striven for. However, as is the case in public politics as well, this is frequently not the case in public space, and majority decisions are often made. Very topical at present in Switzerland, for example, are the debates concerning removal of beggars and young people excessively consuming alcohol from public spaces.

\section{But in a democracy,}

«majority opinions must be justifiable for the minorities so as to be acceptable. That is why the democratic process must be organized in such a way that minorities can put forward their interests and arguments» (LeUENBERGER 2008: 15; translated).

From this perspective, young people consuming excessively alcohol or persons engaging in begging can not simply be expelled from the public space - understood as a place of equal rights to participation - but instead, as negotiation partners having equal rights, they must be included in negotiations on forms of use of the public space. The principles postulated by FINCHER and IvesON (2008): redistribution, recognition, and encounter, for instance, could serve as normative guidelines for this type of negotiation in socially diverse and unequal societies.

However, processes of exclusion from the public space can also occur in a more subtle way. Up until not too long ago in Western societies, for instance, it was deemed unseemly for middle-class women to be in public spaces at night without a male escort (Bond \& Domosh 1998; Ruhne 2003). The reason given for these rules was safety, but in fact the interest was control of women members of society by fathers, husbands, and brothers. While these rules no longer exist today, in the predominant discourse in the media, public spaces, 
especially at night, continue to be depicted as potentially dangerous places for women. As a consequence, many women indeed feel considerably less safe than men do in public space. And so they continue to have themselves be accompanied, or they stay at home, or they avoid specific public places at least temporarily.

The notion that public spaces were ever places where all people had equal rights of participation has today been unmasked by many researchers as a myth (among others, Belina 2005; Bondi \& Domosh 1998). Since public spaces can be understood as a form of social structure (see above), they too are shaped by power and dominance relations. However, this theoretical/ analytical observation does not rule out that the normative logics of equal access can still hold valid for the regulation of public spaces.

\section{The changing function of public spaces}

For some time now, a great deal of attention in the media, politics, and research has been given to the changing function of public spaces. There is currently considerable disagreement as to the direction of this change. Basically, two opposing positions can be identified:

«the position of the skeptics, who see the decline of public spaces with exclusion of socially weaker groups in society, and the position of the optimists, who observe a Renaissance of the public spaces also as a «stage for new selfportrayal by wider classes of society» (WIEGANDT 2006: 7; translated).

Privatization and commercialization are key words that can be linked to the position of the skeptics, while revitalization and reclaiming can be connected with the optimists. However, catchphrases are not very helpful simplifications of reality. It is much more valuable to gain a differentiated view of the use and accessibility of public spaces by examining concrete examples. Careful examinations of this kind are what this special issue is about.

\section{The contributions in this special issue}

The five articles in this special issue represent a (small) selection of the contributions that were presented at the Symposium on Sustainable Public Places of the IGU Commission on Gender and Geography that was held in Zurich, Switzerland, from June 1-3, 2007. All abstracts of the symposium contributions are available for download at http:/www.geo.unizh.ch/nfp54/igu07/ index.html.

In the introductory and somewhat longer paper, «Cities of 〈others〉: public space and everyday practices», DINA VAIOU and Ares Kalandides take up some of the fundamental considerations on public spaces in socially diverse democratic societies mentioned in this editorial. They deepen the examination through various case studies in Berlin and Athens and through critical discussion of central theoretical concepts of public sphere/ private sphere. The contribution by HEIDI KASPAR and ElisABETH BüHLER, «Planning, design and use of the public space Wahlenpark (Zurich, Switzerland): functional, visual and semiotic openness», discusses processes of inclusion and exclusion at a specific public place under the lens of a relational spatial understanding. Based on the same spatial theory, Frank OsterMANN and SABINE TIMPF use visual representation in their contribution, «Use and appropriation of space in urban public parks. GIS methods in social geography» to show that at one and the same place, different people (groups) produce different spaces. Public spaces are very instructional «observatories» for teaching and learning geography. Joos DroogleEver ForTuIJN explicates this argument through presentation of an international comparative study in her contribution «Gendersensitive observations in public spaces as a teaching tool». And the last contribution to this special issue, «Intersections between public and private: community gardens, community service and geographies of care in the US City of Buffalo, NY», by LADonA KNIGGE critically examines the concepts of public space, citizenship, gender, and race - this time looking at an example in the United States.

All in all, the contributions show that the dichotomous categories public space/private space, particularly due to their normative content, continue to be extremely effective in everyday life in socially diverse societies. But as analytical categories they are not very useful, because the boundaries between public and private are fuzzy and are crossed again and again. The same is true of the dichotomies male/female, homosexual/heterosexual or local/foreigner, as explained in the contribution by VAIOU and KALANDIDES.

\section{References}

BeLINA, B. (2005): Öffentlich/privat: von strategischen Grenzziehungen in Gesellschaft und Raum. - In: Berichte zur deutschen Landeskunde 79, 2/3:317-327.

Bondi, L. \& M. Domosh (1998): On the contours of public space: a tale of three women. - In: Antipode 30 3: 270-289

FINCHER, R.\& K. Iveson (2008): Planning and diversity in the city. Redistribution, recognition and encounter. - New York: Palgrave Macmillan.

LeuenBerger, M. (2008): Eigeninteresse und Gemeinwohl in der Politik. Demokratische Legitimierung der Allgemeininteressen. - In: Neue Zürcher Zeitung, June 12, 2008, Zurich: 15 .

Löw, M. (2001): Raumsoziologie. - Frankfurt am Main Suhrkamp.

Ruhne, R. (2003): Raum Macht Geschlecht. Zur Soziologie eines Wirkungsgefüges am Beispiel von 
(Un-)Sicherheiten im öffentlichen Raum. - Opladen: Leske+Budrich.

SCHÄFERS, B. (2003): Ansprüche der demokratisch verfassten Gesellschaft an den öffentlichen Raum. - In: Informationen zur Raumentwicklung, special issue «Öffentlicher Raum und Stadtgestalt»1/2: 15-20. SELle, K. (2008): Spannungsfelder? Öffentliche Räume im Diskurs - und in den Städten. Plätze, Parks und Promenaden. Die Koproduktion der öffentlichen Räume in den Städten. - Aachen: http:/www.pt.rwth-aachen. de/content/view/275/107/lang,en/23. Juni 2008.

Staeheli, L.A. \& D. Mitchell (2007): Locating the public in research and practice. - In: Progress in Human Geography 31, 6: 792-811.
WIEGandT, C.-C. (2006): Öffentliche Räume - öffentliche Träume. Zur Kontroverse über die Stadt und ihre Gesellschaft. Ein kurzes Vorwort. - In: WIEGANDT, C.-C. (ed.): Öffentliche Räume - öffentliche Träume. Zur Kontroverse über die Stadt und ihre Gesellschaft. - Berlin: Lit Verlag: 7-12.

Dr. Elisabeth Bühler, Geographical Institute, University of Zurich, Winterthurerstrasse 190, CH-8057 Zurich, Switzerland.

e-mail: elisabeth.buehler@geo.uzh.ch 